\title{
TERRA SONÂMBULA: A (RE)CONSTRUÇÃO DA IDENTIDADE DO SER AFRICANO A PARTIR DA LÍNGUA PORTUGUESA
}

TIMBANE, Alexandre António ${ }^{1}$ SANTOS, Ivonete da Silva ${ }^{2}$

\begin{abstract}
RESUMO: O presente artigo visa analisar a obra Terra sonâmbula (2007), de Mia Couto, objetivando descrever o modo como o sujeito africano se apresenta identitariamente ao longo do romance por meio da língua portuguesa, uma vez que este ao utilizar a língua do colonizador está de algum modo limitando o uso da língua materna e, por isso, reinventa um novo jeito de viver a sua própria história. Especificamente, demonstrar como e porque as tradições culturais moçambicanas são importantes para a efetivação da identidade linguística, em língua portuguesa, das personagens Tuahir e Muidinga; contribuir para a discussão sobre as questões linguísticas e culturais que influenciam na (re)construção das identidades sociais, sejam elas reais ou fictícias. Ao mesmo tempo que a obra apresenta as personagens Tuahir e Muidinga como reveladoras da realidade e das tradições moçambicanas mostra, também, uma possível transição para um mundo em que a realidade é atormentada por uma guerra que massacra as identidades existentes. E estas se (re)constroem por meio da relação entre o novo e o velho, num diálogo em língua portuguesa.
\end{abstract}

PALAVRAS-CHAVE: Identidade. Língua portuguesa. (Re)construção identitária.

\section{TERRA SONÂMBULA: THE (RE) CONSTRUCTION OF THE IDENTITY OF THE AFRICAN BEING FROM THE PORTUGUESE LANGUAGE}

\begin{abstract}
The present research aimed to analyze the work "Terra sonâmbula" (2007), the Mia Couto, aiming to describe the way in which the africain subject presents himself identitatively
\end{abstract}

Professor, Universidade de Integração Internacional da Lusofonia Afro-Brasileira. E-mail: alextimbana@gmail.com

${ }^{2}$ Doutoranda, Universidade Federal de Catalão. E-mail: nete.silva.santos@hotmail.com

Jangada | nr. 16, jun/dez, 2020 | ISSN 2317-4722

298 | Pá g i n a 


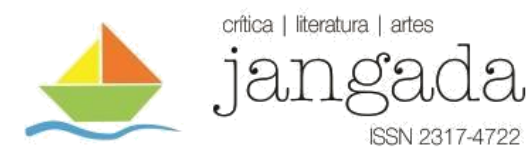

throughout the novel through the portuguese language, since this when using the language of the colonizer it is somehow limiting the use of the mother tongue and, therefore, reinvents a new way of living its own history. Specifically, demonstrate how and why Mozambican cultural traditions are important for the realization of the linguistic identity, in Portuguese, of the characters Tuahir and Muidinga; contribute to the discussion on linguistic and cultural issues that influence the (re) construction of social identities, whether real or fictitious. At the same time that the work presents the characters Tuahir and Muidinga as revealing the reality and the mozambican traditions, it also shows a possible transition to a world in which reality is plagued by a war that slaughters existing identities. And these are (re) constructed through the relationship between the new and the old, in a dialogue in Portuguese.

KEYWORDS: Identity. Portuguese language. Identity (re) construction.

\section{INTRODUÇÃO}

Os desafios envolvidos na empreitada dos estudos que abordam a questão da "identidade" sob a perspectiva da diáspora interna (HALL, 2011), em geral, apresentam certa complexidade, principalmente porque estamos a falar de um assunto que envolve indivíduos que saem do grupo étnico para um espaço físico e psicológico não definido. Mas estes espaços existem como idealizações provenientes da esperança e da busca em fazer parte de um grupo que substitua o grupo étnico de pertencimento, já dilacerado pelos horrores da guerra. Esta busca é empreendida pelas personagens Tuahir e Muidinga, no romance Terra Sonâmbula (2007) de Mia Couto, uma vez que o desejo de sobrevivência durante a guerra as conduz por um caminho que se move dentro do próprio espaço de fuga.

Para leitores críticos da obra ficará claro que as personagens em questão não falam o português de Portugal nem brasileiro. As suas falas carregam muitos traços lexicais, semânticos e sintáticos do Português moçambicano (TIMBANE, 2018). A presença de moçambicanismos vislumbra esse pertencimento identitário que mesmo com as traduções e adequações da editora Companhia das Letras não foi possível eliminar na totalidade. Ao longo da obra é possível perceber que para além do português, os falantes têm conhecimentos de línguas bantu moçambicanas que são também línguas maternas da maioria dos moçambicanos e marcas de identidade da cultura dos povos e etnias a que pertencem. As descrições nos levam a perceber 


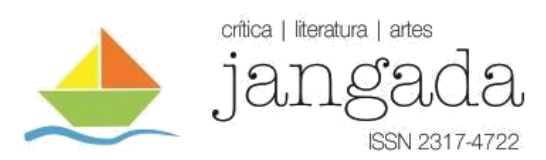

que os eventos (acontecimentos) não ocorrem na cidade, mas sim num ambiente rural onde a presença das plantas e animais selvagens qualifica a história. As descrições espaço-temporais nos levam a compreender como o lado da biologia/meio ambiente envolveu e seduziu o autor das personagens. Na verdade, a guerra em referência no romance não ocorreu no espaço rural, também houve ataques nas cidades de Maputo, Beira, Lichinga, Tete, Chimoio, Xai-xai entre outras, onde a destruição deixou resquícios irreparáveis.

A construção identitária é um processo perpassado pelas experiências dos que se apropriam da identidade (BAUMAN, 2005; SILVA, 2014). Nesse processo estão envolvidas as questões culturais e linguísticas partilhadas pelo grupo de pertencimento de cada sujeito. Em casos como o das personagens em questão, em que essa dinâmica é dilacerada, é natural a (re)construção das identidades existentes. Estas são carregadas de histórias, que, por sua vez, são fatores de identificação dos sujeitos. Na condição de atores sociais, as personagens principais do romance são representantes da cultura moçambicana, que foi sendo aniquilada pela guerra, mas que ainda vive na memória do povo moçambicano.

A busca incessante por uma nova identidade reclama o reencontro com a identidade perdida. Isso porque, no romance, enquanto o velho Tuahir tenta se reinventar por meio de uma nova história, Muidinga, o mais novo, tenta se reencontrar com a sua identidade perdida. Esse reencontro é necessário porque as identidades possuem história, não são estáticas e não estão aí por um acaso. A cultura como uma prática social (CUCHE, 1999) marca presença e estabelece a ordem na vida de uma comunidade.

A identificação dos atores sociais se efetiva por meio da cultura e da língua que juntas comparticipam na dinâmica social. As línguas, segundo Rajagopalan (2003, p. 69), são a própria expressão das identidades dos seus usuários. O que se observa é que os moçambicanos apropriaram-se do português, a língua do ex-colonizador, e a usam como meio de expressão da sua identidade. A variedade moçambicana do português é prova dessa identidade linguística própria. Como a língua é parte da cultura, é também o elemento indispensável ao processo de construção identitária de qualquer indivíduo, porque as diversas possibilidades que o sujeito tem de ver o mundo são dadas pela língua (PERINI, 2004).

O romance de Couto nos permite esse estudo, porque apresenta um confronto entre dois mundos: a realidade cruel (político-militar) e a realidade contida na poesia dos cadernos de Kindzu, que, por sinal, é o motivo que mantém as personagens principais na esperança de uma 


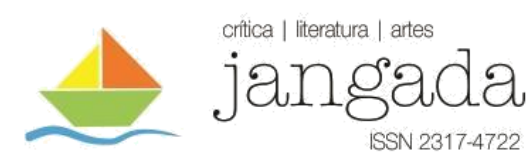

vida melhor, permitindo, ainda, o reencontro com o passado sociocultural, por meio do qual o caráter das tradições moçambicanas são evidenciadas. O fato é que a identidade é flexível e mutável (BRITO; HANNA, 2014), dependendo, principalmente, da dinâmica experienciada pelos seus apropriadores.

Desta feita, objetivamos descrever o modo como o sujeito africano se apresenta identitariamente ao longo do romance por meio da língua portuguesa, uma vez que este ao utilizar a língua do colonizador está de algum modo limitando o uso da língua materna e, por isso, reinventa um novo jeito de viver a sua própria história; demonstrar como e porque as tradições culturais moçambicanas são importantes para a efetivação da identidade linguística, em língua portuguesa, das personagens Tuahir e Muidinga; contribuir para a discussão sobre as questões linguísticas e culturais que influenciam na (re)construção das identidades sociais, sejam elas reais ou fictícias.

O diálogo em língua portuguesa marca a dinâmica do romance, não descartando a importância da transição, vez ou outra, pelas línguas maternas, seja na voz do Tuahir ou nos diálogos empreendidos nos escritos de Kindzu. É importante verificar que a língua portuguesa figura como possibilidade de (re)construção das identidades existentes, apresentando também os prejuízos deixados pela guerra que assola o país. Não falar a língua materna, para Tuahir, significa uma ruptura com o grupo de pertencimento e isso evidencia um sentimento de pertencimento que já não pode mais ser (re)construído.

O presente artigo resulta da nossa inquietação, uma vez que após a leitura atenta do romance de Mia Couto, Terra sonâmbula, percebemos que as personagens atuam num contexto sociolinguístico, histórico e temporal complexo. Quem lê o romance, imediatamente, se vê no espaço e no tempo que realmente ocorreram os eventos narrados, isto é, somos projetados para uma realidade anterior a nós e, assim, faz-se necessário um recorte da identidade sociolinguística que nos permite compreender esses meandros vividos pelas personagens.

Analisamos questões gerais que envolvem o processo de (re)construção, renovação, resistência e abandono das identidades, sejam elas linguísticas ou culturais. Ressaltamos também a necessidade que tem o sujeito de se reinventar por meio da retomada as tradições, bem como da adoção de uma nova língua, o português. As razões que justificam a escolha das 


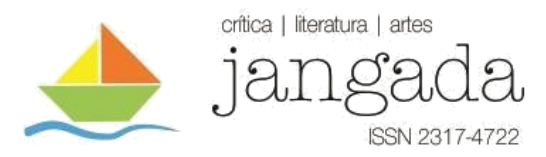

personagens pelo uso do português se revestem pelo viés das políticas linguísticas ${ }^{3}$ em que o português foi escolhido como a única língua oficial num país em que convivem mais de vinte línguas autóctones (TIMBANE; SANTOS; ALVES, 2017).

Para além da introdução, a primeira seção fala da identidade linguística que, em muitos momentos, se liga à identidade cultural numa relação amálgama. É que a língua e a cultura relacionam-se e interferem-se uma na outra. Procuramos mostrar como a identidade forma o sujeito e o diferencia do outro. O que significa dizer que a identidade carrega elementos particulares que marcam o sujeito como parte de um determinado grupo. Na segunda seção, fazemos uma análise dos traços de identidade cultural presentes nas personagens, revelando a identidade e sua relação com a cultura. Na terceira seção, priorizamos a análise dos traços da identidade linguística, considerando-os como fatores de resistência. É por essa razão que algumas das personagens usam a língua local para marcar a presença, ou melhor, o pertencimento a este ou àquele grupo étnico. Na quarta e última seção, o texto apresenta as considerações finais antes de elencar as referências utilizadas.

\section{IDENTIDADES LINGUÍSTICA E CULTURAL: UMA RELAÇÃO AMÁLGAMA}

As questões das identidades linguística e cultural têm sido cruciais para discutir, analisar ou teorizar o processo de identificação do "eu", sujeito socialmente constituído, que se encontra em situações diversas ao longo da sua vida (SANTOS, TIMBANE, 2020). As identidades linguística e cultural mesmo que tratadas ora como identidades à parte, ora como complemento uma da outra são reconhecidas como legitimadoras do sujeito como parte ativa da sociedade, bem como representantes de uma determinada cultura, grupo ou comunidade de pertencimento, sendo responsáveis por situar o ator social às suas referências linguística e cultural socialmente localizadas no tempo e no espaço respectivamente. O que não escapa a essas questões é o modo como essas identidades são formuladas, mudadas, reconstruídas, reafirmadas, recriadas, abandonadas e renovadas.

Em geral, a chamada "identidade" tem o seu processo de produção embasado na relação entre aquilo que é e o que não é. Sinalizando, dessa forma, uma preexistência da diferença,

\footnotetext{
${ }^{3}$ O período da guerra relatada no Romance ocorreu entre 1976-1992, época em que estava vigente a Constituição da República Popular de Moçambique de 1975.
}

Jangada | nr. 16, jun/dez, 2020 | ISSN 2317-4722

302 | Pág in a 


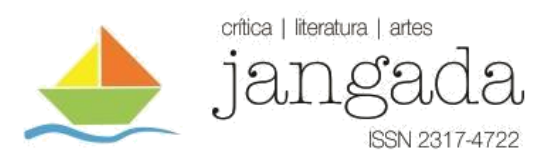

sendo que a identidade como expressão simbólica depende do seu contrário para existir. Em outras palavras, "a identidade e a diferença são estreitamente dependentes da representação. É por meio da representação, assim compreendida, que a identidade e a diferença adquirem sentido. É por meio da representação que, por assim dizer, a identidade e a diferença passam a existir" (SILVA, 2014, p. 91). Dessa forma,

inicialmente, a identidade pode ser entendida como um conjunto de significados definidores de um indivíduo como cumpridor de um papel específico na sociedade, como membro de determinado grupo, com características peculiares que o identificam como uma pessoa única. Essa noção implica, igualmente, numa pluralidade de identidades que o indivíduo carrega, derivada dos muitos papéis exercidos em diferentes grupos, com múltiplas características. Nesse sentido, os significados dessas identidades serão sempre compartilhados com os membros de uma coletividade (BRITO; HANNA, 2014, p. 106).

Nessa lógica, os papéis assumidos pelo ator social ao longo da sua vida perpassam por situações diversas que exigem do sujeito, de algum modo, uma postura completamente adequada às necessidades emergentes de cada situação. Por isso, a identidade não se finda em uma, mas em várias, até porque ela "não é fixa, estável, coerente, unificada, permanente" (SILVA, 2014, p. 96), está em constante transformação. Pertinentemente, a identidade, entendida como plural, está sujeita às coordenadas vigentes na comunidade a qual pertence o sujeito.

$\mathrm{Na}$ perspectiva da identificação, "a identidade é, também, vontade porque supõe, sempre, a adesão de determinado grupo a uma visão específica da realidade" (BRITO; HANNA, 2014, p. 111, grifos dos autores), pois a partilha de valores comuns no seio da comunidade revela não só a origem do grupo, mas também o modo como os seus membros entendem o mundo ao seu redor. Sendo assim, as identidades vigoram em um processo contínuo que se sustenta sempre na relação com o diferente (BRITO; HANNA, 2014). É perceptível que elas só existam em contraponto com o diferente, sendo reestruturadas a partir dessa relação amálgama. Assim, "uma das maneiras pela qual as identidades acabam sofrendo o processo de renegociação, de realinhamento, é o contato entre as pessoas, entre os povos, entre culturas" 


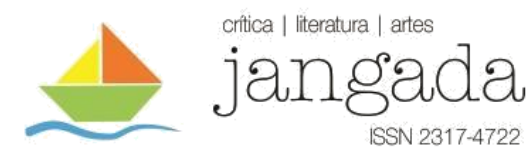

(RAJAGOPALAN, 2003, p. 69). Segundo Silva (2014), a identidade é sinônimo de 'ser' em contrário ao que o outro é, a diferença. Esta marca os limites identitários do 'eu' em relação ao "outro".

As representações provenientes da atuação do ator social dão visibilidade às identidades, uma vez que essas existem de forma abstrata, mas ao serem representadas se tornam concretas e, por isso, podem ser vistas. Sob essa perspectiva, "as identidades caracterizam, pois, os sujeitos de acordo com suas variadas posições na sociedade, fazendo com que indivíduo e sociedade estejam sempre associados quando se pensa em identidade" (BRITO; HANNA, 2014, p. 106).

A heterogeneidade que caracteriza as identidades é resultado do caráter mutável que elas possuem, isto é, “[...] as novas identidades só se criam a partir da exclusão das outras já existentes" (RAJAGOPALAN, 2003, p. 75). Em outras palavras, as configurações que afetam as identidades já existentes, tornando-as novas, recriadas e/ou (re)construídas implicam no processo de escolha e abandono das existentes, sendo que a sua produção está arraigada às situações nas quais se inserem os sujeitos. Isto quer dizer que quando inseridos em uma nova situação, o ator social se sujeita a uma nova adequação, por isso mesmo as identidades são sempre renovadas.

No romance Terra sonâmbula as personagens principais, Tuahir e Muindiga sofrem um processo identitário pautado na busca por uma identidade que os representa, positivamente, na condição em que se encontram no presente, mas para isto percebemos três importantes aspectos motivadores dessa busca: i) o abandono/ rejeição; ii) resgate/ aceitação e; iii) identificação. Estes aspectos são importantes para explicar os conflitos identitários causados diretamente pela guerra que assolou o Moçambique pós-independente, pois "naquele lugar, a guerra tinha morto a estrada. Pelos caminhos só as hienas se arrastavam, focinhando entre cinzas e poeira. A paisagem se mestiçara de tristezas nunca vistas, em cores que se pegavam à boca" (COUTO, 2007, p. 9). É inegável que os horrores da guerra assolavam não só a paisagem, mas, principalmente as vidas que dela tentam sobreviver, uma vez que estas sobrevivem para trilhar novos caminhos, abandonando tudo que lembra essa fase.

Assim, "muitos sentem que a terra tornou-se irreconhecível. Em contrapartida, os sujeitos veem a vida como se os elos naturais e espontâneos que antes possuíam tivessem sido interrompidos por suas experiências diaspóricas [...]" (HALL, 2011, p. 27, grifo nosso), isto 


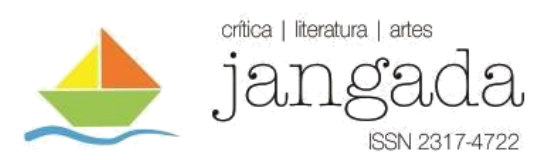

significa que a busca por uma vida diferente da atual é efetivada pela tentativa de fuga de si e do espaço em que ocorrem os horrores da guerra. O desejo de encontrar um novo espaço sem conflitos, em que as personagens possam se fixar para a reconstrução de uma vida nova, marca a busca não só do espaço físico como também do espaço psicológico e identitário. Tudo isso mostra os conflitos vivenciados pelos protagonistas do romance. O mais velho, Tuahir, tenta apagar a identidade existente e o mais novo, Muindiga, luta para resgatar a sua identidade anterior. É diante dessa dualidade que representa duas realidades diferentes e, ao mesmo tempo, complementares, que as identidades linguística e culturais vão sendo transparecidas ao longo do romance.

Como as identidades dependem de um espaço físico em que serão representadas, a sua produção se efetiva a partir da relação amigável entre lugar físico e sujeito, isso porque "há espaços privilegiados: a casa da infância, os trajetos do bairro, recantos da cidade, lugares inseparáveis dos eventos que neles ocorrem. A cidade possui alguns focos sugestivos que amparam nossa identidade, percepção e memória” (BOSI, 2003, p. 114). No romance, o espaço que ampara a (re)construção das identidades das personagens Tuahir e Muindiga é a estrada, aquela que no início foi descrita como morta, isto é, a estrada é, no romance, o lugar da (re)construção identitária dos diaspóricos internos. Chamamos as personagens principais de diaspóricos internos porque estes saem vagando para fora de Moçambique, mas, na verdade, continuam dentro. Prova disso é que "a estrada que agora se abre a nossos olhos não se entrecruza com outra nenhuma. Está mais deitada que os séculos, suportando sozinha toda a distância. Pelas bermas apodrecem carros incendiados, restos de pilhagens" (COUTO, 2007, p. 9), e "os dois caminheiros condiziam com a estrada, murchos e desesperançados" (COUTO, 2007, p. 10).

Como a realidade de idade entre as personagens principais se apresenta com um caráter diferente, é natural que o lugar que sustentou as identidades existentes não seja o mesmo para os dois. Nesse sentido, o olhar do velho Tuahir face à realidade que os abriga é oposta à visão do mais novo, Muidinga. Isto porque

a casa materna é uma presença constante nas autobiografias. Nem sempre é a primeira casa que se conheceu, mas é em que vivemos os momentos mais importantes da infância. Ela é o centro geométrico do mundo, a cidade cresce a partir dela, em todas as direções. Fixamos a casa com as dimensões que ela 


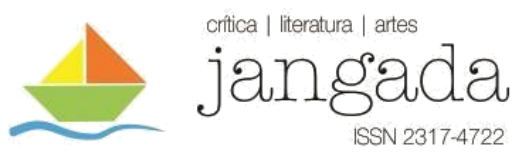

teve para nós e causa espanto a redução que sofre quando vamos revê-la com olhos de adulto (BOSI, 1994, p. 435).

Com isso, a casa que representa a autobiografia de Tuahir não é a mesma que representa a autobiografia de Muidinga. Para este a escola é a principal lembrança, para aquele são os horrores da guerra que assolou a sua comunidade. Para sustentar a (re)construção das novas identidades, as personagens, Tuahir e Muidinga, instalam-se em um autocarro (chamado machimbombo no português moçambicano) queimado/destruído pelo fogo transformando-o em casa. É importante ressaltar que a dinâmica do romance se encontra na relação complementar entre o novo e o velho, sobre o qual ousamos afirmar que o velho se renova através do novo, “o peso da tristeza em sua alma o sufocava [...] perder aquele menino, mesmo que desconhecido, era juntar, simultâneas, todas as variedades de dor" (COUTO, 2007, p. 54), assim como as identidades, sejam elas linguísticas ou culturais. Sobre estas trataremos a seguir, já que são indispensáveis a atuação dos sujeitos no meio social.

\section{IDENTIDADE LINGUÍSTICA}

A língua é referenciada como parte de uma determinada cultura, podendo sobreviver em diversas culturas, o que reforça o seu caráter variável e heterogêneo. Todas as comunidades têm uma língua, ou ainda variedades, que usam como meio de expressão (TIMBANE; SANTOS; ALVES, 2017). Sendo a língua o elemento fundamental que veicula a cultura de um povo, é ela também a expressão desse povo. Isso porque é por meio da língua que a comunidade se constitui como tal e é sob a ideia de união que a língua se torna efetivamente parte da cultura dessa comunidade. Assim, “cada língua é um retrato do mundo, tomando de um ponto de vista diferente, e que revela algo não tanto sobre o próprio mundo, mas sobre a mente do ser humano. Cada língua ilustra uma das infinitas maneiras que o homem pode encontrar de entender a realidade" (PERINI, 2004, p. 52). Pertinentemente, a afirmação de Perini (2004) reforça o caráter servil da língua, ela está no/para os seus usuários e a sua inflexibilidade servil não seria adequada para representar as impressões e os pontos de vista dos falantes em relação ao mundo que os rodeia.

Desta feita, é indispensável à comunidade o uso de uma determinada língua, pois cada língua desempenha na comunidade papéis específicos que respondem aos anseios dos falantes Jangada | nr. 16, jun/dez, 2020 | ISSN 2317-4722 


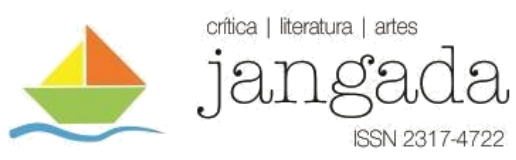

em situações diversas ao longo da sua vida. Isso mostra que as línguas são as diversas maneiras de ver o mundo (PERINI, 2004), ou melhor, elas são as possibilidades que os falantes têm de manifestarem suas impressões sobre tudo ao seu redor, inclusive sobre si e o outro. Em outras palavras, a língua é fator crucial condicionante das identidades individual e coletiva. Sendo assim, “[...] nós, enquanto, usuários da língua, estamos inteiramente à mercê das representações que nossa linguagem nos impõe" (RAJAGOPALAN, 2003, p. 34), até porque as identidades são constructos dessa dinâmica na qual se sujeita o falante.

O modo como o ator social pensa e entende o mundo é resultado da experiência e da relação afetiva que mantém com a língua que usa, sendo ela o veículo principal, pelo qual ele estabelece uma relação comunicativa e interpretativa de si e do grupo do qual faz parte. É por meio da língua que o falante conhece e aprende tudo que o rodeia. A língua é um bem imaterial que funciona para os membros de uma determinada comunidade como fator determinante na construção da identidade individual e coletiva, que intuitivamente os identifica e os localiza dentro do grupo de pertencimento. Pois,

é incontestável que as línguas são o elemento mais importante de uma cultura, de uma sociedade. Seu vínculo estreito com a identidade individual, comunitária e nacional converte a língua ou as línguas [...] em poderosos fatores de tensão política, de sofrimento psicológico, de manipulação ideológica e toda sorte de dinâmica sociocultural. As bandeiras sempre têm sido bandeiras debaixo das quais grupos específicos se reúnem para defender ou reivindicar seus direitos [...] (BAGNO, 2011, p. 356).

Assim, as representações identitárias dependem da língua para serem materializadas, uma vez que é nessa dinâmica que se tornam evidentes as marcas sociais e históricas responsáveis pela elaboração da identidade linguística. Isso porque "o traço mais visível da identidade linguística nesses tempos pós-modernos é a mestiçagem, da qual nenhuma língua escapa hoje em dia" (RAJAGOPALAN, 2003, p. 62). A língua é a própria expressão das identidades, mas como as identidades não são fixas e dependem do tipo de experiência vivida pelos falantes reclama a sua redefinição (RAJAGOPALAN, 2003).

No romance, as identidades linguísticas de Tuahir e Muindinga são reelaboradas por meio da língua portuguesa, apesar da diferença de idade entre os dois. Tuahir é bilíngue, tem Jangada | nr. 16, jun/dez, 2020 | ISSN 2317-4722 


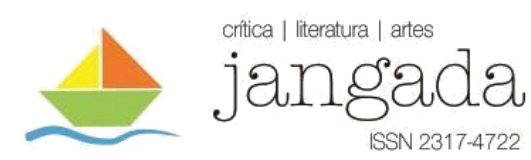

como língua materna uma língua bantu, fazendo uso fluente da língua portuguesa que para ele é a segunda língua. Já para Muidinga a língua portuguesa é a materna, porque ao longo do romance percebemos que ele não demonstra conhecimento da língua bantu, a não ser quando faz uso de palavras resultantes da influência lexical da língua bantu no português. Referimonos aos moçambicanismos lexicais presentes no português falado em Moçambique, por exemplo: matsangas $^{4}$ naparamas $^{5}$, xipoco ${ }^{6}$ ou ainda timaca $^{7}$.

Essa situação representa a dualidade da identidade linguística de que se apropria o Tuahir, mas sob o viés da (re)construção identitária por meio do uso da língua portuguesa que, para além da imposição política, parece representar uma nova possibilidade de vida longe dos horrores da guerra, ou até mesmo da aniquilação de uma identidade linguística anterior, aquela elaborada na língua materna cujas lembranças relembram as dores sofridas pela comunidade de pertença.

Para Tuahir o que interessa é o futuro, "que a nossa terra se ia aquietar, todos se familiariam, moçambicanos. E nos visitaríamos, como nos tempos, roendo os caminhos sem nunca mais termos medo" (COUTO, 2007, p. 67), e é por meio da língua portuguesa que ele deseja a construção de uma vida ideal. Ao dialogar com Siqueleto, que os aprisionou com o intuito de fazer reviver a sua comunidade perdida, Tuahir traduz em português a fala em língua local do indivíduo que os prendeu. Isso demonstra que Tuahir só transita na língua local por essa ocasião, mantendo sempre o uso da língua portuguesa para se comunicar com quem não conhece a língua bantu moçambicana. Quando alguém fala em xichangana, como foi o caso de Siqueleto, a resposta deverá ser na mesma língua do falante, por isso Thuair o respondeu na mesma língua.

Enquanto Tuahir busca uma nova identidade por meio do uso da língua portuguesa, Siqueleto é símbolo de resistência a essa nova identidade, isso porque ele não faz uso do

\footnotetext{
${ }^{4}$ Designação pela qual são conhecidos os bandidos armados. O nome surgiu em homenagem ao primeiro líder desse grupo militar de rebeldes, André Matrangaissa. Os membros desse agrupamento militar foram conhecidos como matsangas. Atualmente, esse grupo tem um partido formalizado: Renamo: Resistência Nacional de Moçambique e tem representantes (deputados) no Congresso Nacional (Assembleia da República).

${ }^{5}$ Grupo de guerreiros civis que lutavam em favor dos militares do governo da Frelimo (Frente de Libertação de Moçambique) e que usavam magia nas suas ações. Esse grupo, não usava armamento bélico, mas sim instrumentos tradicionais: azagaias/arco e flechas, lanças, facões e não eram atingidos por nenhuma bala de fuzis devido a magia negra.

${ }^{6}$ Significa "fantasma". É um empréstimo lexical da língua xichangana para o português moçambicano.

${ }^{7}$ Significa "problemas". É um empréstimo lexical da língua xichangana para o português moçambicano. O singular de "timaca" é "maca". Atenção: a grafia usada por Mia Couto não faz parte da padronização ortográfica. A escrita correta seria "mhàka".
}

Jangada | nr. 16, jun/dez, 2020 | ISSN 2317-4722 
português e, por isso, a sua fala é em língua local, sendo traduzida por Tuahir cujo intuito é fazer com que Muidinga compreenda a conversa. Ao fim do aprisionamento, o aprisionador pede que o nome dele seja gravado em uma árvore, e o mais dotado a fazer isso é Muidinga, que sabe ler e escrever em português, uma vez que, embora Tuahir saiba o português, não o sabe na escrita. E novamente percebemos que toda a dinâmica de um futuro melhor tem como base a língua portuguesa.

No caso da identidade linguística de Muidinga, a sua elaboração perpassa por quem ele era, de onde veio, a que família pertence, “- me conte sobre a minha vida. Quem eu era, antes do senhor me apanhar?” (COUTO, 2007, p. 34). Essa retomada das bases identitárias é importante porque o surgimento de uma nova identidade reclama o reconhecimento das anteriores. As lembranças de Muidinga foram sendo ativadas por meio da leitura, em português, dos cadernos de Kindzu. Por exemplo: "O miúdo lê em voz alta. Seus olhos se abrem mais que a voz que, lenta e cuidadosa, vai decifrando as letras. Ler era coisa que ele agora se recordava saber. [...] A lua parece ter sido chamada pela voz de Muidinga" (COUTO, 2007, p. 14).

$\mathrm{Na}$ tentativa de dar um novo rumo ao moleque, Tuahir decide não ajudá-lo por algum tempo a se reencontrar as suas lembranças. Essa atitude mostra que a rejeição do passado é uma tentativa de elaboração de uma identidade nova, totalmente nova sem os resquícios do passado, assim diz ao garoto “- você nem tem estória nenhuma. Lhe apanhei no campo, ganhei pena de lhe ver aranhiçar, com pernas que já nem conheciam andamento...” (COUTO, 2007, p. 35). Desse modo, os escritos de Kindzu foram incutindo em Muidinga um Moçambique do qual ele não se recordava e até mesmo não conhecia, despertando a curiosidade da vida em comunidade. Ao escrevinhar na estrada, inspirado pelos cadernos de Kindzu, "de súdito, lhe chegam sons [a Muidinga] distantes no tempo, semelhando gritos de meninagem em recreio. $\mathrm{O}$ menino estremece: aquele era uma primeira lembrança. Até ali ele não se recordava de ocorrência anterior à enfermidade" (COUTO, 2007, p. 37). A lembrança é fator de autoafirmação identitária indispensável ao reconhecimento do sujeito dentro de um determinado grupo, no qual são estabelecidas as relações afetivas e/ou não.

Com o passar do tempo, Tuahir vê que não faz sentido poupar o menino das suas origens, pois sem esse saber seria impossível empreender uma nova identidade. Então decide contar-lhe como foi que lhe apanhou: retirou-o do meio dos mortos, a ponto de quase ser enterrado vivo, e o assumiu-o como seu sobrinho para livrá-lo de tal infortúnio. Tuahir cuidou insistentemente 


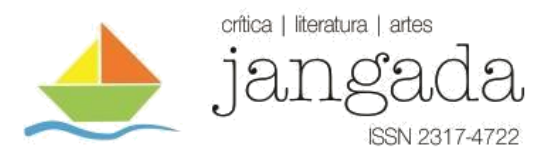

de Muidinga, na certeza de matar a saudade da época que era pai. Vemos aí uma atitude que reforça a necessidade de renovação, uma vez que, como já dissemos anteriormente, o velho se renova através do novo. O próprio nome Muidinga é prova dessa necessidade de resgate da identidade anterior para (re)construí-la, isso porque deu ao garoto o nome de seus filhos, que com ele já não estava.

Portanto, a identidade é a representação linguística da qual se valem aqueles que dela se apropriam. E a sua elaboração não se faz sem que o sujeito estabeleça uma relação afetiva com a língua. Nesse caso, a língua portuguesa é o elo entre o passado e o presente da vida das personagens, funcionando como projeção a um futuro idealizado.

\section{IDENTIDADE CULTURAL}

As práticas comuns a um determinado grupo de pertencimento são saberes partilhados pelos membros desse grupo. A cultura é um conjunto de práticas elaboradas socialmente, é resultado de um processo simbólico do que significa o mundo para o sujeito sob a perspectiva das crenças, das tradições, dos objetos etc. (CUCHE, 1999). A cultura é coletiva, está na memória coletiva e é transmitida de geração em geração. A cultura, segundo Santos e Timbane (2020, p.52), “é um elemento diferenciador, capaz de distinguir um sujeito de outro quando faz parte de universos culturais diferentes..." Tal como a identidade a cultura também se atualiza, pois depende das vivências dos seus produtores.

Segundo Vannucchi (2011), o sujeito é agente cultural, visto que a escolha por um modo de vida típico destaca a opção por este ou aquele grupo. Representar, partilhar e comungar uma cultura é se apresentar como o diferente em relação às demais comunidades, porque a cultura é também identificação. Assim, “a identidade cultural, dessa forma, versa sobre aqueles aspectos de nossas identidades que surgem a partir de nosso senso de pertencimento a distintos grupos étnicos, raciais, linguísticos, religiosos e, acima de tudo, às culturas nacionais" (BRITO; HANNA, 2014, p. 107).

É a partir do desejo de união que o sentimento de pertencimento se torna mais evidente, uma vez que esse sentimento resulta "de um movimento de mão dupla: de exclusão, de diferença diante de uns; de inclusão, de afinidade junto a outros”, (BRITO; HANNA, 2014, p. 111, grifos dos autores). Em outras palavras, pertencer a este grupo e não àquele é uma questão 


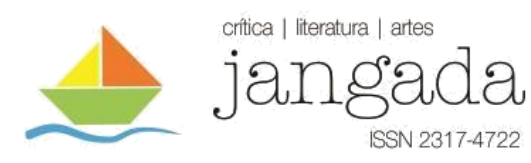

de aceitação dos valores partilhados, enquanto que essa escolha pressupõe a não identificação com outros valores que vigoram em outros grupos, tem-se então a dinâmica entre a inclusão e a exclusão. O pertencimento implica incluir-se para excluir-se (AZEVEDO, 2000, p. 168). Ou seja, pertencer a este grupo e, ao mesmo tempo, não fazer parte de outro grupo.

Segundo Hall (1990) a identificação por meio da cultura resulta da relação entre o passado e o presente que ecoam também no futuro. Pertinentemente, o passado histórico da comunidade é responsável pela elaboração das identidades culturais, pois assim como qualquer outra, a identidade cultural depende de uma base para se renovar. Sendo assim,

possuir uma identidade cultural, nesse sentido, é estar primordialmente em contato com um núcleo imutável e atemporal, ligando ao passado o futuro e o presente numa língua ininterrupta. Esse cordão umbilical é o que chamamos de tradição, cujo teste é o de sua fidelidade às origens, sua presença consciente diante de si mesma, sua autenticidade (HALL, 2011, p. 29, grifos do autor).

Por mais que as situações, principalmente as provindas da diáspora, não sejam homogêneas, sempre será importante ao sujeito o conhecimento e o reconhecimento de sua cultura, ou melhor, da cultura de origem. É por meio dela que o sujeito se torna capaz de se autoafirmar como ser ativo e socialmente constituído. Dessa forma,

o pertencimento e a identidade não têm a solidez de uma rocha, não são garantidos para toda a vida, são bastante negociáveis, e de que as decisões que o próprio indivíduo toma, os caminhos que percorre, a maneira como age - e a determinação de se manter firme a tudo isso - são fatores cruciais tanto para o pertencimento quanto para a identidade (BAUMAN, 2005, p. 17, grifos do autor).

Tanto o pertencimento, quanto a identidade dependem da cultura para acontecerem. Isso pode ser comprovado no romance Terra Sonâmbula. A identidade cultural é uma questão de identidade social (CUCHE, 1999), por meio da qual o sujeito se identifica, localizando-se socialmente. Quando não existe essa referência, ou a identidade se encontra ameaçada, o sujeito passa por um conflito identitário, pois a perda da referência desestabiliza a identidade atual. Ao 


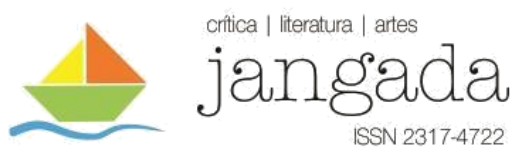

depararem-se com a paisagem devastada pela guerra, Tuahir e Muidinga ficam estarrecidos diante do que veem, "tudo fora abandonado, as culturas se tinham perdido, castanhamente. Terra toda se despira, esperando em vão receber o beijo do arado" (COUTO, 2007, p. 51). Aos poucos os prejuízos deixados pela guerra vão sendo evidenciados ao longo do romance, e isso acabou provocando um colapso nas identidades existentes, “os antepassados ficavam órfãos da terra, os vivos deixavam de ter lugar para eternizar as tradições. Não era apenas um homem, mas todo um mundo que desaparecia" (COUTO, 2007, p. 84). Sem espaço para eternizar as tradições, os que ainda sobrevivem à guerra, Tuahir e Muidinga buscam por um lugar em que possam fazer nascer uma nova comunidade.

A comunidade deve ser vista como ideia de unidade, partilha de costumes e valores tradicionais herdados pelos antepassados. Nesse sentido, o espaço que traz, de certa forma, um conformismo para esse desejo é o machimbombo (ônibus) incendiado no meio da estrada. A falta de identificação cultural ou até mesmo a perda dessa referência dificulta a permanência do sujeito no mundo, uma vez que a sua história cultural é indispensável no processo de significação de tudo o que o rodeia.

O distanciamento da tradição cultural induz o sujeito a situações desagradáveis, o que seria evitado com o conhecimento dessa tradição. Isso ocorre no romance quando Muidinga ao se aventurar pelo mato e se deparar com um grupo de senhoras que estão a por em prática ações tradicionais para espantar gafanhotos das plantações. Ao ser visto por elas, Muidinga é submetido a uma cena um tanto obscena:

então, a mais velha se coloca de pernas abertas sobre seu corpo derrubado e, num puxão, se desfaz da capulana. Aparecem as usadas carnes, enrugadas até aos ossos, os seios pendentes como sacos mortos. Ela grita, se lambe a si mesma, em inesperada volúpias. Sobre a mão por entre as pernas e se deixa cair sobre o rapaz. E se desata a esfregar de encontro ao prostrado Muidinga, mais ciosa que ansiosa. As outras acompanham xiculunguelando, palmando. Uma por uma, todas restantes vãotirando as roupas, trapos e sacos com que se cobriam. Estão nuas, dançando frenéticas à sua volta. A mais idosa dá mais avanço a seus intentos, puxando as íntimas partes do rapaz, abraçada como se lhe quisesse arrancar a alma. Muidinga nem se quer inteirar da sucedência: estava a ser violentado, em flagrante abuso. A primeira se sacia, abusa 
elambuza. Depois, as outras se seguem, num amontanhado de corpus, gorduras e pernas (COUTO, 2007, p. 101).

Submetido a tal abuso e sem entender nada, Muidinga questiona Tuahir sobre o ocorrido. Tuahir, por sua vez, explica ao moço "o que aconteceu foi que aquelas as mulheres estavam em sagrada cerimônia, afastando os gafanhotos que assaltaram as plantações. Elas estavam [...] a esconjurar a maldição. A chegada de um intruso quebrou os mandamentos da tradição" (COUTO, 2007, 101). Como manda a tradição africana, nesse caso, é proibida a presença de homem em cerimônias como essa. Veja como é importante a identificação cultural, o conhecimento da cultura de um povo. O desconhecimento dessa tradição pode induzir o sujeito a situações desagradáveis.

Outro aspecto importante a reparar é que Muidinga é a representação de uma possível comunidade para a qual o Tuahir repassa os aspectos da cultura moçambicana e com isso vai alimentando o jovem com a tradição cultural dos antepassados. Nesse processo de transmissão cultural, Tuahir continua ao longo do romance a ensinar a Muidinga o simbolismo da cultura do seu povo.

Tuahir tem consigo um apito, e uma vez que a cultura depende do processo de significação das coisas, ele vê o objeto como representação do tempo que trabalhara na estação, antes da chegada da guerra, por isso tem o apito como um amuleto, sinônimo de sorte. Em um gesto de gratidão doa-o a Muidinga, o que parece ser a intenção de manter viva a esperança de que o jovem viverá dias melhores, ao passo que ele, em razão da idade avançada, já não ter mais esperança. Então os objetos significam o lugar de origem, bem como ressignificam esse lugar em um novo tempo, de modo que é a cultura da significação dos valores morais e éticos que vigoram em uma comunidade, sem a qual os membros dessa comunidade se encontrariam desolados e deslocados de suas próprias origens.

\section{ANALISANDO TRAÇOS DA IDENTIDADE CULTURAL}

A cultura é uma construção social e a sua manutenção "é um fator importante na constituição cultural do indivíduo se pensarmos que a cultura é também um dos elementos mais significativos, capazes de identificar o sujeito dentro e fora do grupo de origem..." (SILVA; TIMBANE, 2020, p.128). Nas tradições africanas a idade é a mais importante em diversas Jangada | nr. 16, jun/dez, 2020 | ISSN 2317-4722 


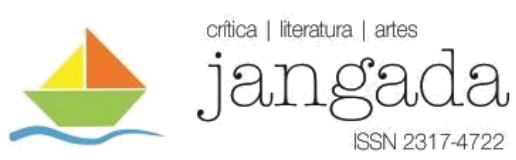

etnias porque os conhecimentos são transmitidos de geração em geração por meio da oralidade. Quanto mais velho for o sujeito maior é a responsabilidade de ensinar os mais novos. Sendo assim, o velho Tuahir se viu na responsabilidade de repassar os conhecimentos aprendidos ao longo da vida para o miúdo (Muidinga). Em muitos momentos não houve explicação das proibições e tabus, porque a filosofia dos povos bantu não deve e nem pode ter explicação. Cabe aos mais novos acatar e seguir, caso o advertido não deseja ver as consequências. Por exemplo:

...o que aconteceu foi que aquelas mulheres estavam em sagrada cerimônia, afastando os gafanhotos que assaltaram as plantações. Elas estavam a enxotálos, a esconjurar a maldição. A chegada de um intruso quebrou os mandamentos da tradição. Nenhum homem pode assistir a esta cerimônia. Nenhum, nunca. (...) É que esses não são gafanhotos próprios. São gafanhotos de alguém. (COUTO, 2007, p.101, grifo do autor).

Vejam que nesta passagem há elementos de identidade cultural (tradições) que o Tuahir tenta transmitir ao Muidinga. O Tuahir tenta explicar, mas espera que o menino cumpra essa prática porque faz parte da identidade da comunidade (etnia) a qual pertencem. Outro exemplo: há uma sensação da falta de medo dos mortos. Isso é aprendido na cultura. A coragem e a resistência contra os obstáculos na vida constituem um dos princípios da cultura. O processo de retirada dos cadáveres do machimbombo, quando lá chegaram pela primeira vez, mostra essa coragem e um olhar diferente perante a morte. Veja-se que o sepultamento ocorreu sem medo. Somente os dois fizeram o sepultamento e em seguida ocuparam o machimbombo. Por outro lado, há uma ruptura causada pela modernidade e pela educação moderna, de forma que quem não sabe ler depende de letrados para decifrar a escrita.

O miúdo (Muidinga) tem habilidades na leitura que causam inveja ao velho analfabeto (Tuahir), ainda que saiba falar o português. Saber falar uma língua não é sinônimo de saber ler nessa mesma língua. São duas modalidades de língua distintas, cada uma exigindo suas habilidades. Se os povos bantu são na grande maioria povos de tradição oral, para Muidinga foi diferente porque sabia ler. Aliás, Kindzu também foi alfabetizado. A leitura permitiu a descoberta da história escrita dos cadernos. Ademais, é muito raro encontrar alguém que tem hábito de escrever diários. 


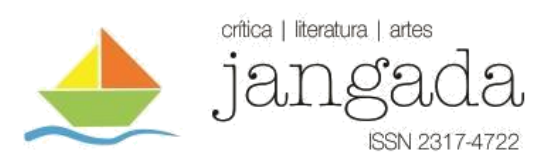

Trata-se de uma nova identidade cultural que se revelou. $\mathrm{O}$ velho Tuahir buscou o conhecimento nos mais velhos e Muidinga, sendo adolescente, busca nos escritos. Por isso, "ler os escritos do morto é um pretexto para ele não enfrentar a escuridão" (COUTO, 2007, p. 35). Aqui temos um duplo sentido: o primeiro, da escuridão real porque já era noite; o segundo, é a sabedoria, porque ler abre as mentes e vislumbra-se um outro mundo, um outro horizonte. Há uma luta de identidade cultural, quer dizer, um deslocamento e formação de novas identidades. Destacamos que Tuahir sempre ficava irritado com a leitura do miúdo, porque o mais velho tem outras referências para buscar o saber.

O conhecimento dos fenômenos da natureza é uma marca da identidade cultural mais presente em Terra sonâmbula. Por exemplo: quando Tuahir e Muidinga caçavam, de repente o miúdo ouviu um som e achou que eram pessoas que se aproximavam para prendê-los. Mas, Tuahir, pela sua experiência, percebeu que não eram passos de humanos e acalmou o menino para não fugir. Afinal, era um elefante que passava (p. 38). Essa atitude de Tuahir mostra o conhecimento que ele tem da natureza. Ele diferenciou o som dos passos de um elefante dos passos de um ser humano. O narrador compara o som dos passos do elefante com a terra sangrando na savana (p. 38). Essa comparação é sábia, uma vez que o país passava por momentos de guerra civil e as pessoas se dispersavam pela savana procurando abrigo e alimentos.

Na p. 51, Muidinga queria comer mandioca amarga, algo que lhe fizera adoecer pela primeira vez, lá no início da história. Graças à intervenção de Tuahir, ele ficou salvo: “o velho junta às pressas os paus de mandioca e lança-os no capinzal". A salvação se deu devido ao conhecimento e a experiência que Tuahir tinha das plantas.

Siqueleto, por sua idade e experiência de vida, revela a capacidade de criar armadilhas para o seu sustento e da sua comunidade. A guerra afastou animais selvagens, de modo que nem sequer conseguiam pegar um animal, até que Tuahir e Muidinga caíram nessa armadinha (p. 58). A armadilha era tão eficiente que nem os intrusos (Tuahir e Muidinga) conseguiram se soltar. Na verdade, Siqueleto não tinha intenção real de comê-los. Como eram estranhos e não sabia de onde vinham, ameaçou-os para compreender até quando iriam resistir. Se Siqueleto estava sem dentes, como iria comê-los? Trata-se de uma estratégia de intimidação ao estranho, ao inimigo. A identidade é ao mesmo tempo espaço. Siqueleto viu o seu espaço invadido. Esses exemplos mostram como a identidade do sujeito é muito mais complexa do que se imagina. 


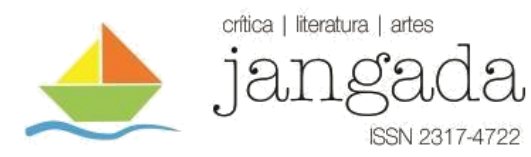

Ninguém conhece os limites da identidade do outro. A vida em sociedade se materializa pelo convívio em sociedade e pela aprendizagem das regras e formas de ser e de estar no grupo social.

Os nomes utilizados pelas personagens são uma resistência às identidades novas. Os nomes provenientes das línguas locais carregam elementos importantes da cultura, como é o caso de Kindzu, Muidinga, Siqueleto e Nhamataca. São nomes de alguma forma identificáveis na etnia tsonga, localizada no Sul de Moçambique. Mas também há que se aceitar a influência europeia em nomes. Temos o caso de Euzinha, Carolinda e Gasparzito.

Outro elemento interessante a notar é relativo à crença nos antepassados. Essa crença faz parte da identidade cultural. No segundo Caderno de Kindzu lê-se: “[...] A viagem mal começava e já o espírito do meu velho me perseguia...” (p. 40). “[...] até meus remos foram motivo de feitiço. Sua madeira começou a verdejar, brotaram-lhe folhinhas: os remos se convertiam árvores [...]” (p. 41). “[...] o xipoco rodou a pá sobre a cabeça, se algazarrando em berreira [...]" (p. 42). Esses exemplos são suficientes para mostrar que a obra toda está cheia de elementos sobrenaturais e crença nos antepassados. Essa é uma identidade sociocultural presente nas tradições, e na cultura à qual as personagens do romance pertencem. Não se trata de uma ficção, mas sim retrato da sociedade bantu.

\section{ANALISANDO TRAÇOS DA IDENTIDADE LINGUÍSTICA E SUA RESISTÊNCIA}

A língua se liga à cultura. Muitos elementos da cultura se juntam à língua. Neste romance há uma presença de duas línguas: a língua portuguesa e a língua xichangana. A língua portuguesa se manifesta por meio da variedade que é mais comum na fala dos moçambicanos. Ao ler o texto é possível verificar a presença de moçambicanismos que são marcas próprias do português falado em Moçambique. Por exemplo: “A chuva timbilava no tecto do machimbombo. Os dedos molhados do céu se entretinham naquele tin-tin-tilar. Tuahir está embrulhado numa capulana" (p. 123). As palavras destacadas no exemplo, ocorrem no português moçambicano. Só neste exemplo, há vários elementos que podemos analisar: primeiro, a palavra timbilar que vem do substantivo "timbila" que é o nome de um instrumento musical parecido com xilofone. Há aqui um processo de transformação de substantivo "timbila" em verbo "timbilar". 


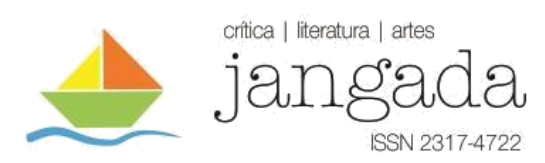

A segunda palavra é "machimbombo" que significa "ônibus, autocarro". A palavra se forma por meio de empréstimos do inglês: machine (maquina)+pomp (explosão). A terceira palavra, tin-tin-tilar, é a formação de um verbo partindo de uma onomatopeia. É um fenômeno recorrente nas línguas bantu, especialmente na formação de ideofones. Finalmente, capulana é nome de um pano/tecido de cores variadas que as mulheres amarram na cintura, ou embalam as crianças, ou ainda fazem roupas. $\mathrm{O}$ uso dos moçambicanismos na fala das personagens revela uma afirmação da identidade que a variedade carrega. Trata-se da afirmação da moçambicanidade que sempre se manifesta na variedade linguística.

Outra forma de identidade presente nas personagens do romance é a tradução das expressões das línguas bantu moçambicanas para o português. Neste caso, temos o exemplo vindo da língua xichangana: "Santanhoco, u ta dhá lithulu" que significa "Diabo, comerás a poeira”. A versão em língua xichangana usa-se quando alguém quer afirmar que não vai poder alcançá-lo ou quando quer advertir que "não vai conseguir algo". No texto temos a frase: "Satanhocos, hão-de comer poeira" (p. 66). O uso no português de expressões vindas das línguas locais marca uma identidade linguística moçambicana porque a identidade linguística é uma construção social resultante da memória que os falantes preservam ao longo dos tempos, de modo que a aprendizagem da língua ocorre na família e cabe aos pais ensinar (SILVA; TIMBANE, 2020).

As personagens usam vários neologismos lexicais e semânticos que tornam o texto mais belo e mais artístico. Couto (2007) disponibiliza no fim do livro um glossário para facilitar o entendimento seus leitores não moçambicanos. Mas isso não basta porque há outros elementos que não aparecem no glossário que só são facilmente compreendidos pelos falantes da variedade moçambicana do português.

\section{CONSIDERAÇÕES FINAIS}

Tuahir e Muidinga são personagens reveladoras da realidade e das tradições moçambicanas, visto que nelas subjazem resíduos oníricos fundamentais nos imaginários populares oriundos de diferentes etnias. São representantes do mosaico cultura linguístico que caracteriza Moçambique. Nas estórias de Kindzu são evidenciados fragmentos orais de lendas que perpassam o sobrenatural e que são simbolismos da cosmovisão tão própria do povo africano. 


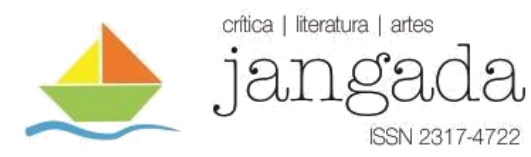

Nessa dinâmica, importa destacar a relação intercultural entre etnias diferentes, fato que marca a miscigenação das identidades evidenciadas ao longo do romance tanto no escritos quanto na realidade cruel de que sobrevivem Tuahir e Muidinga.

Tuahir é a representação típica do sujeito que deseja se reconstruir identitariamente, como tentativa de uma vida melhor. Ao adotar Muidinga, Tuahir demonstra o quão forte é esse desejo de vida nova. Isso evidência que a relação entre o velho e novo é fator condicionante da continuidade da vida sob a esperança de que as lembranças ruins sejam aniquiladas. A tentativa de evitar o passado empreendido pelo Tuahir é reflexo dos prejuízos deixados pela realidade cruel que acometeu sua comunidade, seu grupo de pertencimento. Experiências como essas provocam, no sujeito, o desejo de sair para fora do espaço físico e/ou psicológico cuja intenção será sempre a busca por uma nova forma de identificação linguística e cultural. Mas, como bem discutimos nas seções anteriores, a nova identidade depende do reconhecimento das identidades anteriores. Prova disso é a busca incessante do Muidinga pelo conhecimento da história pessoal.

Por outro lado, o jovem Muidinga representa a retomada da identidade perdida. Essa busca em retrocesso é um caminho necessário para que as identidades anteriores sejam renovadas e reconstruídas. Isso porque as identidades possuem histórias e dependem de experiências vivenciadas pelos seus apropriadores.

Importante ressaltar que o diálogo que condiciona o conhecimento das identidades perdidas e a (re)construção delas é empreendido em língua portuguesa, o que evidencia a importância da língua na construção das identidades. Enquanto Tuahir (re)constrói sua identidade por meio da língua portuguesa como expectativa de viver novos tempos, Muidinga resgata sua identidade anterior também por meio da língua portuguesa, mas o resgate é uma tentativa de se reconhecer dentro de um grupo, pois as identidades nos situam na cultura de origem e na comunidade de pertencimento. Para tal a língua é indispensável.

A estrada e o machimbombo são, por um período, o local que ressignifica a vida das personagens, proporcionando a elas o reencontro com o passado cultural da comunidade de pertencimento, fato este conseguido por meio da leitura, em português, dos escritos de Kindzu. Ao fim dessa estadia, as personagens saem em busca dos seus objetivos: Tuahir deseja morrer no mar e Muidinga deseja conhecer o mar. Tais desejos parecem retomar um país em que a comunidade se encontrará em perfeita harmonia. 


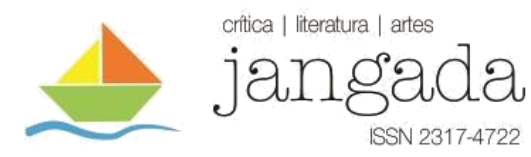

Portanto, a reconstrução das identidades das personagens do romance se efetiva com o resgate das lembranças das tradições culturais, em uma dinâmica que envolve a resistência, adaptação, a renovação, a aceitação e, por fim, a identificação de si, face à realidade que vivenciam. Essas identidades não se apresentam concluídas, até mesmo porque, a imersão dos sujeitos em diferentes situações os conduzem a um novo processo de renovação das identidades existentes. Elas são configuradas e movimentadas quando da mudança social das personagens. Por isso, o processo identitário é marcado pela transição em que o passado se faz necessário ao presente, e estes são determinantes ao futuro idealizado.

Por fim, é nítido que o romance apresenta uma relação amálgama entre língua, cultura e identidade, pois as primeiras são indispensáveis à identificação. Nenhum indivíduo convive em sociedade sem que a sua atuação seja evidenciada por meio da identificação social e isso nos revela quais são os aspectos culturais e linguísticos comuns ao grupo de pertencimento. Sem o sentimento de pertencimento "a" o sujeito se sente desolado e deslocado no mundo, tentando sempre se reencontrar e se realocar em um determinado grupo.

\section{REFERÊNCIAS BIBLIOGRÁFICAS}

AZEVEDO, J. Culturas: a construção das identidades. In: Africana Studia. no 3, Porto, p. 165$182,2000$.

BAGNO, M. O que é uma língua? Imaginário, ciência \& hipóstase. In: LAGARES, X. C.; BAGNO, M. (Org.). Políticas da norma e conflitos linguísticos. São Paulo: Parábola Editorial, 2011.

BAUMAN, Z. Identidade. Tradução de Carlos Alberto Medeiros. Rio de Janeiro: Jorge Zahar, 2005.

BOSI, E. O tempo vivo da memória: ensaios de psicologia social. 2.ed. São Paulo: Ateliê Editorial, 2003.

Memória e Sociedade: lembranças dos velhos. 3.ed. São Paulo: Companhia das Letras, 1994.

BRITO, R. P.; HANNA, V. L. H. Busca identitária em espaço lusófono: Timor-Leste. In:

BASTOS, Neusa Barbosa (Org.). Língua portuguesa e lusofonia. São Paulo: Ed.PUC-SP, 2015.

COUTO, M. Terra Sonâmbula. 17. ed. São Paulo: Companhia das Letras, 2007.

Jangada | nr. 16, jun/dez, 2020 | ISSN 2317-4722

319 | Pá g i na 
CUCHE, D. A noção de cultura nas ciências sociais. Tradução de Viviane Ribeiro. Bauru: Edusc, 1999.

HALL, S. Cultural identity and diáspora. In: RUTHERFORD, J. (Org.). Identity: community, culture, difference. Londres: Lawrence Wishart, 1990.

HALL, S. Da diáspora: identidades e mediações culturais. Tradução de Adelaine La Guardia Rezende et.al. Belo Horizonte: Ed. UFMG, 2011.

PERINI, M. A. A língua do Brasil amanhã e outros mistérios. São Paulo: Parábola, 2004.

RAJAGOPALAN, K. Por uma linguística crítica: linguagem, identidade e a questão ética. São Paulo: Parábola Editorial, 2003.

SANTOS, I. S.; TIMBANE, A. A. A identidade linguística brasileira e portuguesa: duas pátrias, uma mesma língua? Curitiba: Appris, 2020.

SILVA, T. T. da. A produção social da identidade e da diferença. In: SILVA, T. T. da; HALL, S.; WOODWARD, K. (Org.). Identidade e diferença: a perspectiva dos estudos culturais. 15.ed. Petrópolis: Vozes, 2014.

TIMBANE, A. A. A variação linguística do português moçambicano: uma análise Sociolinguística da variedade em uso. In: Revista Internacional Em Língua Portuguesa, (32), 19-38, 2018.

TIMBANE, A. A.; SANTOS, I. da S.; ALVES, M. J. Os caminhos da variação léxicosemântica no Brasil, em Portugal e em Moçambique. In: PAULA, M. H. de; SANTOS, M. P. dos; PERES, S. M. (Org.). Perspectivas em estudos da linguagem. São Paulo: Blucher, 2017. VANNUCCHI, A. Cultura brasileira: o que é, como se faz. 5. ed. São Paulo: Edições Loyola, 2011. 